\title{
Adolescent bulimia nervosa (BN): a new therapeutic frontier
}

\author{
Kim Hurst ${ }^{1}$, Shelly Read ${ }^{2 *}$, Tiegan Holtham ${ }^{2}$ \\ From 2014 ANZAED Conference: Driven Bodies Driven Brains \\ Fremantle, Australia. 22-23 August 2014
}

Enhanced Cognitive Behaviour Therapy (CBT-E) continues to gather evidence as the first line of treatment for Bulimia Nervosa (BN) in adulthood. However, there is limited evidence for empirically validated therapies for children and adolescents, despite the serious impact of medical complications during adolescence.

In recent years, investigation into the effectiveness of Family Based Treatment (FBT) for BN has been instigated. It has been proposed that FBT may be particularly helpful for BN, by combating the secretive and shameful nature of $\mathrm{BN}$, and increasing adolescent collaboration. The following case study contrasts the delivery of FBT to two adolescents presenting with $\mathrm{BN}$; one is augmented with CBT-E.

In both cases, the adolescents achieved remission from BN symptoms, with a cessation of bingeing and/or compensatory behaviours at the end of treatment. Parents and adolescents reported feeling as though FBT provided a platform to work together and view $\mathrm{BN}$ as a family issue, rather than leaving the onus on the young person to recover independently. Both families reported higher levels of cohesion at the end of treatment, and parents reported feeling more empowered to help their offspring. The application of specific CBT-E strategies was also reported as integral in achieving recovery. Further research in this area is indicated.

This abstract was presented in the Treatment in Community and Inpatient Settings stream of the 2014 ANZAED Conference.

\section{Authors' details}

${ }^{1}$ Eating Disorder Program, Gold Coast CYMHS, Robina, Australia. ${ }^{2}$ CYMHS Gold Coast, Robina, Australia.

\footnotetext{
* Correspondence: shellyreadpsychology@hotmail.com.au

${ }^{2}$ CYMHS Gold Coast, Robina, Australia

Full list of author information is available at the end of the article
}

Published: 24 November 2014

doi:10.1186/2050-2974-2-S1-06

Cite this article as: Hurst et al: Adolescent bulimia nervosa (BN): a new therapeutic frontier. Journal of Eating Disorders 2014 2(Suppl 1):O6.
Submit your next manuscript to BioMed Central and take full advantage of:

- Convenient online submission

- Thorough peer review

- No space constraints or color figure charges

- Immediate publication on acceptance

- Inclusion in PubMed, CAS, Scopus and Google Scholar

- Research which is freely available for redistribution

Submit your manuscript at www.biomedcentral.com/submit

\section{Ciomed Central}

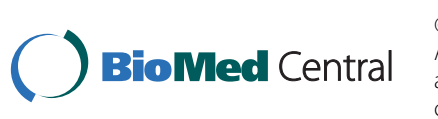

(C) 2014 Hurst et al; licensee BioMed Central Ltd. This is an Open Access article distributed under the terms of the Creative Commons Attribution License (http://creativecommons.org/licenses/by/4.0), which permits unrestricted use, distribution, and reproduction in any medium, provided the original work is properly cited. The Creative Commons Public Domain Dedication waiver (http:// creativecommons.org/publicdomain/zero/1.0/) applies to the data made available in this article, unless otherwise stated. 